\title{
The Effectiveness of Inquiry Learning Models Intervened by Reflective Processes to Promote Critical Thinking Ability in Terms of Cognitive Style
}

\author{
https://doi.org/10.3991/ijet.v15i16.14687 \\ Ni Nyoman Sri Putu Verawati $\left.{ }^{(}\right)$, Hikmawati \\ Universitas Mataram, Mataram, Indonesia \\ veyra@unram.ac.id \\ Saiful Prayogi \\ Universitas Pendidikan Mandalika, Mataram, Indonesia
}

\begin{abstract}
This study aims to explore the effectiveness of inquiry learning models intervened by the reflective process to promote the critical thinking ability of preservice teachers in terms of cognitive style. This study is a quasiexperimental research with one-group pretest posttest design. The research sample involved 24 preservice physics teachers who studied at the Physics Education Department - Mandalika University of Education (Undikma). Cognitive style measurement uses the Group Embedded Figures Test (GEFT) to identify groups of preservice teachers into the field dependent (FD) or field independent (FI) cognitive style. Measurement of critical thinking ability using test instruments in the form of essays consisting of 8 test items. Critical thinking ability score is analyzed descriptively and statistically, where the normality test and paired t-test was conducted. The results of the study show that as many as 13 preservice teachers are categorized into the FD cognitive style and 11 categorized into the FI cognitive style. The average pretest score of the two cognitive style groups (FD and FI) was 0.87 with the criteria of "less critically", and after the implementation of the inquiry learning model intervened by the reflective process, the average posttest score was 16.25 with the criteria of "critically," and n- a gain of 0.64 with the criteria of "moderate." These results indicate that the inquiry learning model intervened by the reflective process is effective to promote critical thinking ability of preservice teachers with FD and FI cognitive styles.
\end{abstract}

Keywords-Inquiry learning models, reflective processes, critical thinking ability, cognitive style.

\section{Introduction}

Retention, understanding, and active use of knowledge can be created only by learning experiences where students are able to think. Some experts conclude that humans do not have a natural tendency to think critically. Even highly motivated people often don't think critically [1]. Critical thinking is the domain of high-level thinking, where high-level thinking can and should be taught at all levels of educa- 
tion, especially at the level of higher education $[2,3]$. Learning at the higher education level based on academic principles not only provides professional skills, but also general skills such as critical thinking to learners [4]. Optimizing the achievement of critical thinking in learner is when they study at the higher education level. When in higher education, learners are faced with broader and complex problems that require critical thinking [5]. Developing learners' critical thinking means supporting their academic freedom [6]. In addition, critical thinking is very important for the future role of learners as citizens in a democratic society, and supports their work abilities in the future [7]. Critical thinking has been defined as a set of cognitive abilities or skills related to the process of logical analysis and evaluation of arguments $[8,9]$. Ennis $[10,11]$ argue that critical thinking as a reasonable and reflective thought that focuses on deciding what to believe or do.

John Dewey as a philosopher and psychologist has long introduced the concept of critical thinking. Dewey introduced critical thinking as reflective thinking [12]. Referring to this concept, previous researchers $[13,14,15,16]$ have conducted studies on critical thinking. Interestingly, they found that learners cannot think critically because teachers do not integrate the process of achieving critical thinking with learning practices that require some reflection. Theoretically, it cannot be denied that critical thinking as sensible and reflective thinking, but the concept of reflective thinking as a precursor to training critical thinking has not been adequately researched, most studies have not provided effective strategies on how to combine these two concepts, ultimately the need for practicing critical thinking does not find much success [17]. Teaching critical thinking ability in the classroom requires a holistic approach and must involve a set of appropriate and goal-oriented learning models that allow learners to manipulate their cognitive skills [18, 19, 20,21].

Learning to improve the critical thinking ability, especially in science learning has been widely carried out including through inquiry activities [22, 23, 24]. According to Skamp [25], an effective science learning strategy is to give students the opportunity to conduct independent investigations by linking learning to everyday life and the environment. The intended science learning strategy is inquiry [26]. Inquiry is in accordance with constructivist principles, which gives learners the opportunity to build new understanding based on experience by exploring various phenomena in the environment [27]. In addition, many of the objectives of inquiry activities focus on critical thinking abilities, for example; identifying assumptions, using logical thinking, analyzing direct events and phenomena, critical analysis of secondary sources, analyzing arguments by reviewing current scientific understanding, considering evidence, and logic examining [28]. However, the implementation of inquiry in the field often ignores the core of the critical thinking process, namely the reflective process. The tendency of the implementation of the inquiry model so far still emphasizes learning to find and test concepts or facts in a simple way, whereas the core of the learning process is how learners can regulate thinking not only theoretically but also practically to be used in more complex contexts [22]. Regulation of thought when the learning process is part of the reflective process that can support the success of learning according to the expected goals [29]. 
In its implementation in the classroom, the inquiry model needs to be intervened by reflective processes that aim to promote critical thinking ability. This study aims to explore the effectiveness of the inquiry learning model intervened by the reflective process to promote critical thinking ability of preservice teacher in terms of cognitive style. Cognitive style in learning is important to consider, because the critical thinking ability is related to the earner's cognitive style [30]. The relationship is how individuals receive, store, process and present information with a high level of consistency that will affect the behavior and activities of individuals both directly and indirectly [31]. Someone with a field-dependent (FD) cognitive style can think globally, accept and follow available information, and tend to prioritize external motivation, whereas someone who has a field-independence (FI) cognitive style is good at analyzing objects that are separate from their environment, classifying objects, and prioritizing internal motivation [32]

\section{Methodology}

This study is a quasi-experimental study, where one-group pretest posttest design is conducted. The sequence of this research process are sample selection, measurement of cognitive style using the Group Embedded Figures Test (GEFT), pretest, treatment (learning with inquiry models intervened by reflective processes), posttest, and finally analysis of results. The study sample involved 24 preservice teachers (14 male and 10 female) in the Physics Education Department - Mandalika University of Education (Undikma), with an average age between 19-21 years. Cognitive style measurement uses GEFT as many as 18 item items (figure test) to identify the sample group into the cognitive style FD or FI [33]. Pretest and posttest to measure the critical thinking skills of the sample, where the instrument used was in the form of essay questions consisting of 8 items. Treatment in this study is to implement an inquiry model that intervenes in the reflective process. The learning is carried out during four meetings on the subject of fluid mechanics, each meeting lasting about 150 minutes.

The GEFT score is 0 and 1, if the correct answer is given a score of 1 and if the wrong answer is given a score of 0 . The individual GEFT score is interpreted into two categories, the cognitive style of FD if the acquisition scores from 0 to 11 , and the cognitive style of FI if scores from 12 to 18 . Meanwhile, each individual's critical thinking ability scores are analyzed using a multilevel scale (five scales) with the lowest score -1 (minus one) and the highest +3 (plus three). Furthermore, the critical thinking scores (CTs) of each preservice teachers are interpreted into the categories of very critically $(\mathrm{CTs}>17.6)$, critically $(11.2<\mathrm{CTs} \leq 17.6)$, quite critically $(4.8<\mathrm{CTs} \leq$ $11.2)$, less critically $(-1.6<\mathrm{CTs} \leq 4.8)$, and not critically (CTs $\leq-1.6)[2,21,23]$. The effectiveness of the inquiry model intervened by the reflective process to promote critical thinking ability is characterized by an increase in the critical thinking ability scores. Analysis of increasing scores using the n-gain equation, where if $n$-gain is > 0.70 then the criteria for increasing scores are high, 0.30 to 0.70 has moderate criteria, and $<0.30$ has low criteria [34]. Data analysis of critical thinking skills is done descriptively and statistically, where the normality test and t-test (pait-t test) are conducted. 


\section{Results and Discussion}

The GEFT analysis shows as many as 13 preservice teachers are categorized into the FD cognitive style and as many as 11 categorized into the FI cognitive style. The results of the measurement of preservice teachers' critical thinking ability before and after the implementation of the inquiry model intervened by the reflective process for each cognitive style are presented in Table 1 and Table 2, where the average score of critical thinking at the time of the pretest for groups of students with FD cognitive style is $0.84(\mathrm{n}=13)$ with the criteria of "less critically" $(-1.6<\mathrm{CTs} \leq 4.8)$ and the average posttest score was 16.23 with the criteria of "critically" $(11.2<\mathrm{CTs} \leq 17.6)$, with an increase in the average score of critical thinking (n -gain) is 0.62 with the criteria of "moderate." Whereas for the group of preservice teacher with FD cognitive style, the average score of critical thinking at the time of the pretest is $0.91(\mathrm{n}=11)$ with the criteria of "less critically" $(-1.6<\mathrm{CTs} \leq 4.8)$ and the posttest average score is 16.27 with the criteria of "critically" $(11.2<\mathrm{CTs} \leq 17.6)$, with n-gain of 0.66 with the "moderate" criteria.

Table 1. The results of the measurement of critical thinking ability

\begin{tabular}{|c|c|c|c|c|c|c|c|}
\hline \multirow{2}{*}{ Nu. } & \multirow{2}{*}{$\begin{array}{c}\text { Cognitive } \\
\text { style }\end{array}$} & \multicolumn{2}{|c|}{ Pretest } & \multicolumn{2}{|c|}{ Posttest } & \multirow{2}{*}{ n-gain } & \multirow{2}{*}{ Criteria } \\
\hline & & CT score & Criteria & CT score & Criteria & & \\
\hline 1 & FI & -1 & less critically & 15 & critically & 0.64 & moderate \\
\hline 2 & FI & -1 & less critically & 17 & critically & 0.72 & high \\
\hline 3 & FD & 4 & less critically & 18 & very critically & 0.70 & moderate \\
\hline 4 & FD & -1 & less critically & 17 & critically & 0.72 & high \\
\hline 5 & FI & 1 & less critically & 17 & critically & 0.69 & moderate \\
\hline 6 & FD & 3 & less critically & 14 & critically & 0.52 & moderate \\
\hline 7 & FD & 2 & less critically & 15 & critically & 0.59 & moderate \\
\hline 8 & FD & -1 & less critically & 14 & critically & 0.60 & moderate \\
\hline 9 & FD & 0 & less critically & 17 & critically & 0.71 & high \\
\hline 10 & FI & -1 & less critically & 19 & very critically & 0.80 & high \\
\hline 11 & FI & 3 & less critically & 16 & critically & 0.62 & moderate \\
\hline 12 & FD & 0 & less critically & 18 & very critically & 0.75 & high \\
\hline 13 & FI & 3 & less critically & 17 & critically & 0.66 & moderate \\
\hline 14 & FI & 3 & less critically & 17 & critically & 0.66 & moderate \\
\hline 15 & FI & 3 & less critically & 15 & critically & 0.57 & moderate \\
\hline 16 & FD & 0 & less critically & 18 & very critically & 0.75 & high \\
\hline 17 & FI & -1 & less critically & 16 & critically & 0.68 & moderate \\
\hline 18 & FD & 3 & less critically & 14 & critically & 0.52 & moderate \\
\hline 19 & FD & 3 & less critically & 17 & critically & 0.67 & moderate \\
\hline 20 & FD & 0 & less critically & 16 & critically & 0.67 & moderate \\
\hline 21 & FI & 2 & less critically & 15 & critically & 0.59 & moderate \\
\hline 22 & FD & -1 & less critically & 18 & very critically & 0.76 & high \\
\hline 23 & FI & -1 & less critically & 15 & critically & 0.64 & moderate \\
\hline 24 & FD & -1 & less critically & 15 & critically & 0.64 & moderate \\
\hline
\end{tabular}

Overall, the results in Table 2 show that the average pretest score of the two cognitive style groups $(n=24)$ was 0.87 with less critical criteria and posttest was 16.25 
with critical criteria, with n-gain of 0.64 with "moderate" criteria. These results indicate that there is an increase in the critical thinking ability of preservice teacher for each cognitive style after the implementation of the inquiry model intervened by the reflective process.

Table 2. Comparison of the average scores of critical thinking ability for FD and FI cognitive styles

\begin{tabular}{|c|c|c|c|c|c|c|c|}
\hline \multirow{2}{*}{$\begin{array}{l}\text { Cognitive } \\
\text { style }\end{array}$} & \multirow[b]{2}{*}{ Nu. } & \multicolumn{2}{|c|}{ Pretest } & \multicolumn{2}{|c|}{ Posttest } & \multirow[b]{2}{*}{ n-gain } & \multirow[b]{2}{*}{ Criteria } \\
\hline & & $\begin{array}{c}\text { CT score } \\
\text { average }\end{array}$ & Criteria & $\begin{array}{l}\text { CT score } \\
\text { average }\end{array}$ & Criteria & & \\
\hline FD & 13 & 0.84 & less critically & 16.23 & critically & 0.62 & moderate \\
\hline FI & 11 & 0.91 & less critically & 16.27 & critically & 0.66 & moderate \\
\hline Average & & 0.87 & less critically & 16.25 & critically & 0.64 & moderate \\
\hline
\end{tabular}

Differences in critical thinking ability scores were statistically tested using the ttest (pair-t test), where the normality test of the data as a prerequisite test was carried out. The results of the normality test showed that the data variant was not normally distributed (the significance value of 0.003 was smaller than alpha testing). Because the data are not normally distributed, the pair t-test uses the Wilcoxon test. The results of the pait-t test are shown in Table 3 .

Table 3. The result of pair t-test using Wilcoxon among pretest and posttest score

\begin{tabular}{|l|c|c|c|c|c|}
\hline & N & Mean rank & Sum of rank & Z & Sig. \\
\hline Negative Ranks & 0 & 0.00 & 0.00 & -4.296 & 0.000 \\
\hline Positive Ranks & 24 & 12.50 & 300.00 & & \\
\hline Ties & 0 & & & & \\
\hline Total & 24 & & & & \\
\hline
\end{tabular}

The negative value of critical thinking rank is 0 for $n$, mean rank, and sum of rank which shows that there is no decrease in the pretest score for the posttest of all preservice teachers. This means that as many as 24 preservice teachers have increased critical thinking scores (positive rank). Ties also have a value of 0 which indicates there is no equal score between the pretest and posttest of each preservice teachers. Furthermore, the results of the pair-t test showed that the significance value $(0.000)$ was smaller than alpha testing (0.05), meaning that there were differences in the scores of preservice teachers' critical thinking ability between pretest and posttest. The elaboration of the results of this analysis is very clear that the inquiry learning model intervened by the reflective process is effective to promote preservice teachers' critical thinking ability in both groups of preservice teachers with FD and FI cognitive styles.

An important finding of this study is that the inquiry model that intervened in the reflective process is suitable to be implemented to learning to promote critical thinking ability with the characteristics of both field dependent and field independent cognitive styles. The critical thinking aspects measured in this study are analysis, inference, evaluation, and decision making. The results of previous studies [35] showed 
that learners with FI cognitive styles tended to be stronger in using their critical thinking than FD. Likewise, the results of a study by Listiagfiroh \& Ellianawati [36], their findings were that FI learners were better at critical thinking compared to FD learners. The FD learners need guidance in the process of solving problems and the use of critical thinking. However, an important finding from this study is that with the treatment of inquiry learning models intervened by the reflective process, preservice teachers' critical thinking ability can be promote and the results are those with cognitive styles both FD and FI show good performance in critical thinking. Reflective in inquiry learning requires learners to be curious, open-minded, and responsible for the knowledge they have or is being explored. Furthermore, reflective learning requires learners to carry out a systematic self-evaluation cycle through open discussion or written analysis during the learning process facilitated by the instructor [37]. The forms of reflective process intervention in inquiry teaching that support the critical thinking of preservice teachers are monitoring- process, control-process, evaluation of performance, and sustainable reflection [22, 29].

\section{Conclusion}

The implementation of the inquiry model intervened by the reflective process can promote the critical thinking ability of preservice teachers with both FD and FI cognitive styles. The critical think ability of preservice teachers increased from less critically to critically after the implementation of the inquiry model intervened by the reflective process. These results indicate that the inquiry learning model intervened by the reflective process is effective to promote the critical thinking ability of preservice teachers with FD and FI cognitive styles.

\section{Acknowledgement}

This study is part of the University's Flagship Research with the theme of Developing Reflective-Inquiry Learning (RIL) Models to Improve Critical Thinking Ability of Preservice Teachers in Term of Cognitive Style. This research was fully funded by the government of the Republic of Indonesia. We thank those who have contributed in supporting this study, including research partners. We hope that this study will benefit education progress especially in Indonesia and globally.

\section{References}

[1] Machperson, R. \& Stanovich, K. E. (2007). Cognitive ability, thinking dispositions, and instructional set as predictors of critical thinking. Learning and Individual Differences, 17(2), 115-127. https://doi.org/10.1016/j.lindif.2007.05.003

[2] Verawati, N.N.S.P., Prayogi, S., Gummah, S., Muliadi, A. \& Yusup, M.Y. (2019). The effect of conflict-cognitive strategy in inquiry learning towards pre-service teachers' critical 
thinking ability. Jurnal Pendidikan IPA Indonesia, 8(4), 529-537. https://doi.org/10.15294/ jpii.v8i4.21002

[3] Prayogi, S., Yuanita, L. \& Wasis. (2018). Critical-Inquiry-Based-Learning: A model of learning to promote critical thinking among prospective teachers of physic. Journal of Turkish Science Education, 15(1), 43-56. https://doi.org/10.1088/1742-6596/947/1/012013

[4] Erikson, M. G. \& Erikson, M. (2019). Learning outcomes and critical thinking - good intentions in conflict. Studies in Higher Education, 44(12), 2293-2303. https://doi.org/10.10 80/03075079.2018.1486813

[5] Andrews, R. (2015). Critical thinking and/or argumentation in higher education. In the Palgrave handbook of critical thinking in higher education, edited by M. Davies \& R. Barnett, 49-62. New York: Palgrave Macmillan. https://doi.org/10.1057/9781137378057_3

[6] Macfarlane, B. (2017). Freedom to learn - The threat to student academic freedom and why it needs to be reclaimed. London: Routledge. https://doi.org/10.4324/9781315529455

[7] Barnett, R. (2011). Being a university. Abingdon: Routledge.

[8] Facione, P. A. (2000). The disposition toward critical thinking: Its character, measurement, and relationship to critical thinking skills. Journal of Informal Logic, 20(1), 61-84. https:// doi.org/10.22329/il.v20i1.2254

[9] Stupnisky, R. H., Renaud, R. D., Daniels, L. M., Haynes, T. L. \& Perry, R. P. (2008). The interrelation of first-year college students' critical thinking disposition, perceived academic control, and academic achievement. Research in Higher Education, 49(6), 513-30. https:// doi.org/10.1007/s11162-008-9093-8.

[10] Ennis, R. H. (2011). Critical thinking: Reflection and perspective part II. Inquiry: Critical Thinking Across the Disciplines, 26(2), 5-19. https://doi.org/10.5840/inquiryctnews201126 $\underline{215}$

[11] Ennis, R. H. (2013). Critical thinking across the curriculum: The wisdom CTAC Program. Inquiry: Critical Thinking Across the Disciplines, 28(2), 25-45. https://doi.org/10.5840/in quiryct 20132828

[12] Fisher, A. (2003). Critical thinking an introduction. Cambridge: Cambridge University Press.

[13] Choy, S.C. \& Cheah. (2009). Teacher perceptions of critical thinking among students and its influence on higher education. International Journal of Teaching and Learning in Higher Education, 20(2), 196-204

[14] Rudd, R. D. (2007). Defining critical thinking. Techniques, 82(7), 46-49.

[15] [15] Black, S. (2005). Teaching students to think critically. The Education Digest, 70(6), $42-47$

[16] Vaske (2001). Critical thinking in adult education: An elusive quest for a definition of the field. Unpublished doctoral thesis, Drake University, Des Moines, Iowa

[17] Choy, S. C. \& Oo, P. S. (2012). Reflective thinking and teaching practices: A precursor for incorporating critical thinking into the classroom? International Journal of Instruction, 5(1), 167-182.

[18] Prayogi, S., Muhali, Yuliyanti, S., Asy'ari, M., Azmi, I. \& Verawati, N. N. S. P. (2019). The effect of presenting anomalous data on improving student's critical thinking ability. International Journal of Emerging Technologies in Learning, 14(6), 133-137. https://doi. org/10.3991/ijet.v14i06.9717

[19] Prayogi, S., Yuanita, L. \& Wasis. (2017). Critical-Inquiry-Based-Learning: Model of learning to promote critical thinking ability of pre-service teachers. Journal of Physics: Conference Series 947, 1-6. https://doi.org/10.1088/1742-6596/947/1/012013

[20] Wahyudi, Verawati, N.N.S.P., Ayub, S., \& Prayogi. (2018). Development of inquirycreative-process learning model to promote critical thinking ability of physics prospective 
teachers. Journal of Physics: Conf. Series 1108, 1-6. https://doi.org/10.1088/1742-6596/11 $\underline{08 / 1 / 012005}$

[21] Wahyudi, Verawati, N. N. S. P., Ayub, S. \& Prayogi, S. (2019). The effect of scientific creativity in inquiry learning to promote critical thinking ability of prospective teacher. International Journal of Emerging Technologies in Learning, 14(14), 122-131. https://doi. org/10.3991/ijet.v14i14.9532

[22] Verawati, N.N.S.P., Hikmawati \& Prayogi, S. (2019). Conceptual framework of reflectiveinquiry learning model to promote critical thinking ability of preservice physics teachers. Journal of Physics: Conference Series 1397, 1-10. https://doi.org/10.1088/1742-6596/139 7/1/012009

[23] Wahyudi, Verawati, N.N.S.P., Ayub, S. \& Prayogi, S. (2019). Effectiveness of inquirycreative-process learning model to promote critical thinking ability of prospective physics teachers. Journal of Physics: Conference Series 1417, 1-6. https://doi.org/10.1088/1742-65 $\underline{96 / 1417 / 1 / 012071}$

[24] Prayogi, S., Muhali, Yuliyanti, S., Asy'ari, M., Azmi, I. \& Verawati, N. N. S. P. (2019). The effect of presenting anomalous data on improving student's critical thinking ability. International Journal of Emerging Technologies in Learning, 14(6), 133-137. https://doi. org/10.3991/ijet.v14i06.9717

[25] Skamp, K. (1998). Teaching Primary Science Constructively. C. MacKenzie, Ed. Victoria: Harcourt Australia Pty Ltd.

[26] Artayasa, I. P., Susilo, H., Lestari, U. \& Indriwati, S. E. (2018). The effect of three levels of inquiry on the improvement of science concept understanding of elementary school teacher candidates. International Journal of Instruction, 11(2), 235-248. https://doi.org/10. $\underline{12973 / i j i .2018 .11216 \mathrm{a}}$

[27] Ketpichainarong, W., Panijpan, B., \& Ruenwongsa, P. (2010). Enhanced learning of biotechnology students by an inquiry-based cellulose laboratory. International Journal of Environmental \& Science Education, 5(2), 169-187.

[28] Bailin, S. (2002). Critical thinking and science education. Science and Education, 11(4), 361-375.

[29] Verawati, N. N. S.P. \& Hikmawati. (2019). Validitas model inkuiri yang diintervensi proses reflektif untuk melatih kemampuan berpikir kritis mahasiswa calon guru. Prisma Sains: Jurnal Pengkajian Ilmu dan Pembelajaran Matematika dan IPA IKIP Mataram, 7(1), 38-47. https://doi.org/10.33394/j-ps.v0i0.1408

[30] Woolfolk, A. (2009). Educational Psychology. New York: Pearson

[31] Wright, R. A., \& McCurdy, B. L. (2012). Class-wide positive behavior support and group contingencies: Examining a positive variation of the good behavior game. Journal of Positive Behavior Interventions, 14(3), 173-180. https://doi.org/10.1177/1098300711421008

[32] Witkin, H. A, Moore, C. A, Goodenough, D. \& Cox, P. W. (1977). Field-dependent and independent cognitive style and their educational implication. Review of Educational Research 47 (1), 1-64. https://doi.org/10.3102/00346543047001001

[33] Witkin, H.A, Oltman, P.K Raskin, E. (1971). Manual embedded figure test, children embedded figure test, grup embedded figure test. California: Consulting psychology press, Inc.

[34] Hake, R, R. (1999). Analyzing change/gain scores. AREA-D American Education Research Association's Division Measurement and Research Methodology.

[35] Kholid, M. N., Hamida, P. S., Pradana, L. N. \& Maharani, S. (2020). Students' critical thinking depends on their cognitive style. International Journal of Scientific \& Technology Research, 9(1), 1045-1049. 
[36] Listiagfiroh, W. \& Ellianawati. (2019). Problem based learning: Practicing students' critical thinking skills with cognitive style dependent fields and independent fields. Jurnal Penelitian dan Pengembangan Pendidikan Fisika, 5(2), 169-176. https://doi.org/10.21009/1 .05212

[37] Choy, S. C., Yim, J. S. C., \& Tan, P. L. (2017). Reflective thinking among preservice teachers: A Malaysian perspective. Issues in Educational Research, 27(2), 234-251

\section{$7 \quad$ Authors}

Ni Nyoman Sri Putu Verawati is a lecturer in fundamental physics course, Department of Physics Education, Universitas Mataram - Indonesia. Her study concern in exploration the preservice teachers' critical thinking ability.

Hikmawati is a lecturer in physics learning course, Department of Physics Education, Universitas Mataram - Indonesia. Her study concern in exploration the science process skills.

Saiful Prayogi is a lecturer in physics education, Department of Physics Education, Universitas Pendidikan Mandalika - Indonesia. His study concern in development of critical thinking instruments assessment.

Article submitted 2020-04-06. Resubmitted 2020-05-26. Final acceptance 2020-05-27. Final version published as submitted by the authors. 